\title{
A history of the American Society for Clinical Investigation
}

\author{
Joel D. Howell \\ Department of Internal Medicine, Department of History, and Department of Health Management and Policy, \\ University of Michigan, Ann Arbor, Michigan, USA.
}

\begin{abstract}
One hundred years ago, in 1909, the American Society for Clinical Investigation (ASCI) held its first annual meeting. The founding members based this new society on a revolutionary approach to research that emphasized newer physiological methods. In 1924 the ASCI started a new journal, the Journal of Clinical Investigation. The ASCI has also held an annual meeting almost every year. The society has long debated who could be a member, with discussions about whether members must be physicians, what sorts of research they could do, and the role of women within the society. The ASCI has also grappled with what else the society should do, especially whether it ought to take a stand on policy issues. ASCI history has reflected changing social, political, and economic contexts, including several wars, concerns about the ethics of biomedical research, massive increases in federal research funding, and an increasingly large and specialized medical environment.
\end{abstract}

One hundred years ago, in 1909, the world seemed engulfed by revolutionary ideas. Sigmund Freud was touring the United States to lecture on a far-reaching new concept called psychoanalysis; the architect Frank Lloyd Wright was putting the finishing touches on Robie House in Chicago, which still looks contemporary today; Richard Strauss premiered his operatic version of the ancient Greek tragedy of Electra, whose dissonant, lush chromatic score still sounds modern a hundred years on; and Sultan Abdul Hamid II, the last Ottoman sultan to rule with absolute power, was being deposed by the Young Turks, who hoped to bring sweeping reforms to the Ottoman empire.

Radical new ideas were sweeping the biological sciences as well. Knowledge of human disease had been reshaped throughout the 1800 s by careful correlation of bedside clinical signs with pathological autopsy findings. However, near the century's end, creative laboratory techniques were opening new areas for study. Investigators identified the microbial organisms responsible for specific diseases: first tuberculosis, then many more. Physicians applied innovative technologies in physiological laboratories to analyze organ function in health and disease.

But most of these medical changes were taking place outside of the United States. Within the United States, contemporary observers bemoaned the fact that "The poverty of the resources of the medical institutions was truly pitiful" (1). The major exception to this glum landscape was the Rockefeller Institute for Medical Research in New

Citation for this article: J. Clin. Invest. 119:682-697 (2009). doi:10.1172/JCI39091.
York City (Figure 1), founded in 1901 by the oil magnate John D. Rockefeller and headed by the young physician Simon Flexner (whose brother Abraham, a Louisville Latin teacher, was soon to author a report on medical education). A handful of scientists were employed at the Rockefeller Institute to do laboratory-based research.

But there was precious little such opportunity elsewhere. Even at the best US medical schools, professors had little use for the ideology of scientific medicine. They saw its results as unimportant and tended at best to ignore and at worst to ridicule its findings (2, 3). Medical practice based on the natural sciences - so-called allopathic medicine (the term for current MD practice) - existed in tenuous coexistence with a variety of other fields, such as homeopathy, chiropractic, and osteopathy. At the turn of the 20th century, it was unclear which type of medicine was destined to succeed. (Ironically, even as he supported scientific research at the Rockefeller Institute and elsewhere, John Rockefeller was personally averse to allopathic medicine and preferred to be treated by homeopathic remedies; his institute - and later hospital - was founded on the advice of one of his trusted advisers.)

In 1886 elite leaders of US medical schools had banded together to found the Association of American Physicians (AAP). Tellingly, they also considered naming the organization the "Association of Physicians and Pathologists" $(4,5)$. This alternative name reflected their dominant model of medical research, which was firmly rooted in older, pathology-based ideas about how to do medical research. Basing their scholarly approach on evidence provided by postmortem pathological findings, 19th-century physicians had 


\section{Figure 2}

The New Willard Hotel in Washington, DC, site of the first $\mathrm{ASCl}$ meeting in 1909. Several decades previously, US President Ulysses S. Grant used to relax in the lobby of the Willard. People wishing to influence him would come and talk with him there - according to one version of the history, this led to the term "lobbyist." (Courtesy of Willard Intercontinental Washington.)

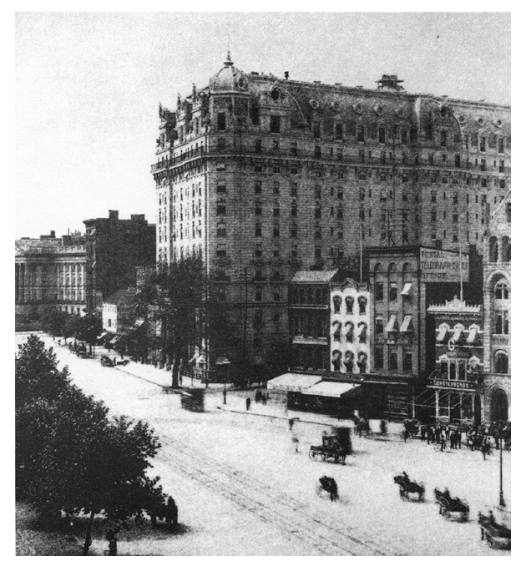

effectively identified the anatomic sites of many important disease processes (6). A generation of elite American physicians had traveled to train in Europe and then used these ideas to transform teaching and education in a handful of US medical schools. But near the end of the century, clinicopathological correlation was reaching the limits of its explanatory possibilities. As the 20th century dawned, AAP members by and large remained solidly rooted in the ideas and ideology of the previous century.

Because the AAP limited its membership, a handful of clinical investigators who worked with newer, more innovative scientific techniques decided to strike out on their own. At 10 a.m. on May 10, 1909, fifteen physicians, many in their early thirties, gathered at the historic and newly remodeled New Willard Hotel in Washington, DC, to inaugurate a new society (Figure 2). They heard an opening address by a German-trained physiologist and physician entitled "The Science of Clinical Medicine: What It Ought to Be and the Men to Uphold It" and then settled in to hear twelve scientific talks. A century hence, this event does not sound all that exciting. Yet by the standards of the day, what this group was doing was nothing less than revolutionary. Who were these men? Why were they there? What did they accomplish? Why has the organization they founded, the American Society for the Advancement of Clinical Investigation (soon thereafter changed to the current American Society for Clinical Investigation) survived - even thrived - for over a century?

This article will discuss some answers to these questions. This is "a" history of the first century of the ASCI, not "the" history. That distinction is important, for no history is ever complete or definitive (7). As the distinguished scholar Christopher Hill has noted, "History has to be rewritten every generation, because although the past does not change the present does" (8). Thinking (and rethinking) about ASCI history appears to be an unwritten requirement for several generations of ASCI presidential addresses. Those addresses (most of which have been published) are useful as both secondary and primary historical sources.

Over the course of the past century, the ASCI has promoted biomedical research. It has also been part of some of the less pleasant aspects of 20 th century biomedicine. I have noted these negative episodes, as they are clearly part of the history, but I have not dwelled on them. At the end of the article, I consider questions that have repeatedly confronted the ASCI over the century. This history is by no means comprehensive. There are many fascinating but untouched questions for future historians to explore.

\section{The birth of a society}

The ASCI started as an idea of the physician and scientist Samuel J. Meltzer, born in 1851. As a medical student in Germany, Meltzer volunteered for studies on swallowing in which he had two stomach tubes placed in his esophagus. In the midst of one of these experiments, the laboratory was unexpectedly visited by the Prussian minister of education, who carefully noted Meltzer's uncomfortable situation. Soon thereafter, anti-vivisectionists introduced a bill claiming that experimentalists would not dream of inflicting the same suffering on themselves as they would on animals. The minister enlightened the legislative debate by relating his observations of Meltzer's role in the experiments and asking whether those advocating the bill would be willing to put themselves in Meltzer's place. No one volunteered. The bill failed $(9,10)$.

Germany was one of the leading countries for doing medical research. But being a Jew precluded his obtaining an academic position, and after graduation Meltzer wanted to continue doing clinical research there. Had he been willing to convert to Christianity, Meltzer could have pursued a career in his homeland. Instead, after several transatlantic trips working as a ship's surgeon, he settled in New York City in 1885, where he practiced medicine and did physiological research during his spare time. One can only imagine his delight when in 1904 he was asked to join the research group at the Rockefeller Institute (Figure 3). There he studied swallowing mechanisms and magnesium's inhibitory effects on muscles, studies leading to the use of magnesium to treat tetanus. He also invented a tracheal tube for ventilating patients, an idea soon taken up by surgeons (11, 12). But despite his many accomplishments, at the end of his career, Meltzer continued to be seen by some as an outsider, marked by speaking the "broken English of the immigrant" (13).

In addition to his scientific work, Meltzer had a penchant for bringing people together. In 1903 he founded the Society for Experimental Biology and Medicine, which is still going strong.

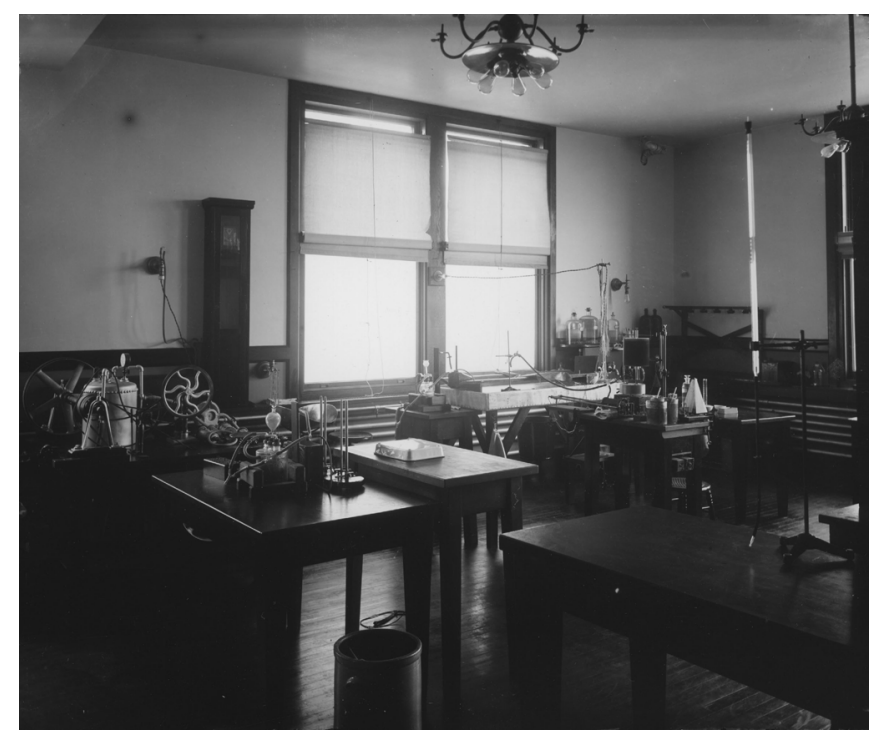

Figure 3

Samuel Meltzer's physiology laboratory at the Rockefeller Institute. Meltzer's ideas and leadership led to the formation of the ASCl. He emphasized the importance of not relying on older ideas of autopsybased research, but rather of using the latest in laboratory techniques. (Courtesy of the Rockefeller Archive Center.) 


\section{Figure 4}

ASCl members have approached research topics by using the latest and most sophisticated technology. At the initial ASCl meeting, the dominant new technology was the newly invented Riva-Rocci cuff for measuring blood pressure. (Reproduced from ref. 132.)

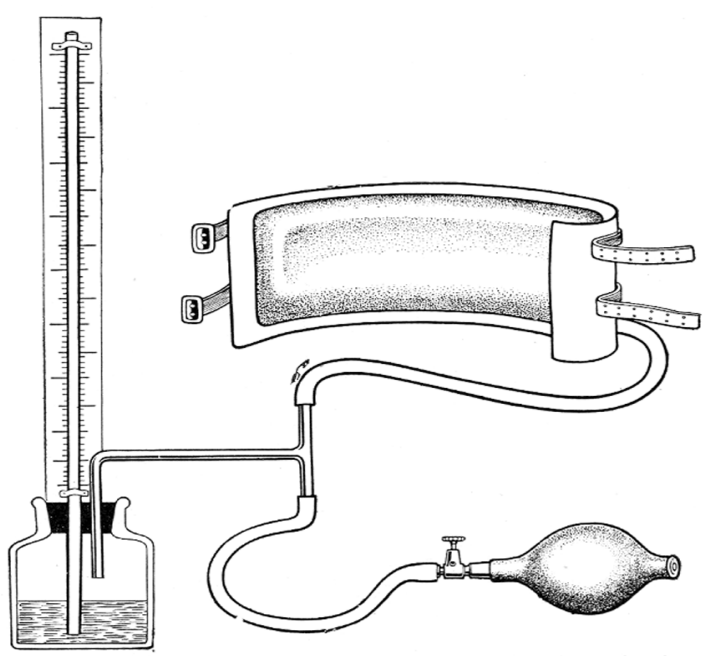
FIG. I69.- The simplest form of a sphygmomanometer, for the determination of arterial blood
pressure. This is the Riva-Rocci type, the first of the successful sphygmomanometers, and still perhaps
Some years later, as the threat of a world war loomed on the horizon, Meltzer feared for the international fellowship of scientists. Believing that medical men ought to promote morality, he founded a society of physicians for international good will called Fraternitas Medicorum (14). The society engaged thousands of members around the world, but it did not survive the US entry into the First World War.

Meltzer was also concerned about the woeful state of clinical research in the United States (15). At the June 1907 American Medical Association meeting in Atlantic City, Meltzer suggested the formation of a new society "whose prime purpose should be the encouragement of medical research in this country by men engaged actively in the practice of medicine" (ref. 16, p. 1). In other words, this was to be a US society for active clinicians. At follow-up meetings, the organizers decided that the society would be limited to active investigators. Members were to be chosen on the basis of publications in the past five years (i.e., membership was not a reward for work done long ago); to remain eligible, members needed to remain active researchers, as evidenced by publishing an original investigation at least once every three years.

After some organizational issues were worked out, the first annual ASCI meeting was gaveled to order on a rainy spring day in 1909. Meltzer's opening address foresaw an exciting future. He warned members against spending too much time in clinical practice, for which one would only be rewarded with a gilded tombstone. Meltzer also stressed that contemporary clinical research should not be founded on the "dead house" science of pathology that had characterized the previous generation, but on the active, progressive science of physiology (17).

Follow Meltzer's stirring words, Haven Emerson (grand-nephew of the poet Ralph Waldo Emerson) presented the initial ASCI scientific talk, "The Blood Pressure in Tuberculosis" (18). Emerson's presentation reflected an apt juxtaposition of topics. Known since antiquity, tuberculosis had recently been brought into sharper focus by Robert Koch's stunning 1882 discovery in Germany of the causative bacillus. To study patients with this disease, Emerson used a novel technology. The Italian physician Scipione RivaRocci had described the first clinically useful means of measuring blood pressure only in 1896 . Emerson's studies thus creatively applied a new technology to a newly understood disease, a famil- iar investigative pattern over the years to come. Indeed, measurement of blood pressure (Figure 4) was a central focus of four of the first twelve ASCI presentations.

The physicians who met at the New Willard Hotel that May day were not only friends and colleagues, but also fellow revolutionaries. Their goal was to move clinical research away from what they saw as a stagnating emphasis on pathological correlation and toward a scientific basis grounded in new, more progressive sciences. Members saw themselves as striking a blow against the established orthodoxy, much like the Young Turks of the Ottoman Empire who were then trying to rejuvenate the Turkish Empire. ASCI members labeled themselves the "Young Turks" and frequently used the term to refer to themselves in their correspondence.

\section{Early years}

ASCI meetings over the next few years followed patterns similar to that of the first one, with a move to Atlantic City in 1911. When not meeting, members were active investigators who were required to present a paper at the meeting at least once every three years (ref. 16, p. 7). They also had to attend regularly; those who missed meetings without an adequate excuse were dropped from the roll (ref. 16, p. 53).

Not much went on between meetings, save discussions about recruitment. The ASCI Council encouraged existing members to recruit new ones, saying that "the council cannot make nominations, and we therefore ask that each member consider carefully whether there are not some men of his acquaintance ... who merit election to the society. Many clinicians well trained in scientific methods yield to the demands of increasing practice and abandon laboratory investigations" (ref. 16, p.48). This warning reflected the increasing appeal of full-time clinical practice in an era in which the practicing physician's status (and income) was rapidly increasing (a danger Meltzer had noted in his inaugural address).

By its 1914 meeting, the ASCI had enrolled more than 70 members. The increasing size forced the first length limits on presentations: ten minutes for the talk, five minutes for discussion. Papers for oral presentation also started to be limited to only the first 30 titles submitted to the secretary (cut down to 25 in 1916) (ref. 16, pp. 74, 78). Papers were accepted simply on a first-come, 
first-served basis until 1922, when the Council decided, "owing to the fact that the present way of making up the program does not always lead to the best selection," to leave selection of papers for presentation "to the discretion of the president" (ref. 16, p. 235). Also in 1914, not for the last time, a change to the meeting format was proposed. Meltzer suggested a multiple-day meeting so that more members could present a paper, saying the ASCI need not act like an appendix to the "older Association of American Physicians." His suggestion was not adopted. The original name was thought to be too unwieldy and in 1916 was shortened from the original American Society for the Advancement of Clinical Investigation to simply the American Society for Clinical Investigation over the other suggested designation, the "American Society of Internal Medicine.”

The First World War started in Europe in 1914; the United States formally entered the conflict in 1917. It hit medical schools hard. George Blumer of Yale University devoted his 1918 ASCI presidential address to "Medical Education in Relation to the War." His presentation was noteworthy for at least two reasons. First, he spoke publicly and forcefully on matters of public policy - and the question of whether and how the ASCI should advocate policy positions would continue to be debated throughout the century. Second, his concern over threats to the "very existence of the schools" speaks both to the broad-based impact of the war and the precarious nature of the newly reformed medical schools. The war ended later in 1918, and the next year, members were cautioned not to let the disorganized postwar environment curtail their "investigative spirit" (and advised against joint authorship) $(19,20)$.

Both the medical schools and ASCI thrived in the postwar period. Being elected to the ASCI meant more than merely an honor to be listed on a vita. Members looked forward to socializing at each annual meeting, to listening to others' talks, and to hearing useful criticism of their own work. Physicians came to see the ASCI as their first choice for presenting a paper. The AAP was a second choice, to be used only if the paper was not going to make it onto the ASCI program (21).

ASCI meetings were held on the eastern seaboard. Because the time and money required for train travel posed a difficult or insurmountable obstacle to many clinical investigators, particularly those who lived in the interior of the country, ASCI President Leonard Rowntree suggested in 1921 that it might be a good idea to form local societies, especially for younger investigators (22). But the next year, an ASCI committee said it was "inadvisable" to establish branch societies, opining that in all large cities, there are "medical organizations in which the young man in internal medicine may become a member and thus obtain the stimulation which arises from contact with others." Instead, the committee urged ASCI members to stay in touch with younger men of special promise.

Perhaps the answer was not branch societies but a new society. A group of 12 midwestern physicians (7 of whom were ASCI members) met in 1919 to consider ways to overcome the geographical difficulties. After prolonged discussion, in 1927 they wrote to the ASCI about their desire to form a new society. Ernest Irons, who as an intern cared for the first patient described with sickle cell anemia and who soon was to be dean of Rush Medical College, explained that "the point was to give the younger men in the middle West a chance to read their papers and get the benefit of criticism as well as the honor of getting into the society." In no way was this intended to be a rival society. The ASCI Council replied that the "foundation of a new Society had the best wishes of the Ameri- can Society for Clinical Investigation, but that the latter did not want to participate actively in its formation." The Council went on to say that it "heartily endorses this move and recommends that the Society extend its best wishes for the immediate success of the new society." The first formal meeting of the ASCI-inspired Central Society for Clinical Research was held in 1928 in Chicago. For almost two decades, the ASCI published the Central Society meeting abstracts in the Journal of Clinical Investigation (JCI), a new journal to whose creation we now turn (23).

\section{The Journal of Clinical Investigation}

The year 1924 saw the establishment of the JCI. As early as 1916, ideas about such a journal had been floated to the board of directors of the Rockefeller Institute, but nothing was done. In 1921 the director of the Rockefeller Institute Hospital, Rufus Cole, sent the board a detailed 14-page memo explaining the rationale for establishing a new journal (24). He pointed out the need to encourage clinical investigation, noting that "relatively few consciously organized scientific investigations of medical problems have been undertaken in our university departments of medicine or by men trained in the study of disease at the bedside." Part of the problem was that people who did clinical research had a hard time finding an appropriate journal in which to publish. Well-established clinical research journals existed in other countries, such as Germany, France, and England. But in the United States, while the Rockefeller-supported Journal of Experimental Medicine provided an outlet for pure laboratory work, there was no good place for people whose primary goal was the "control and cure of disease" to publish their work. Cole claimed that "there would be no serious lack of material to supply a journal of the character proposed," listing several universities doing work that could be published in a new journal and asserting that papers from the hospital of the Rockefeller Institute alone over the past 10 years could fill nine volumes. No action immediately followed this 1921 memo.

Two years later, the noted internist and dean of Vanderbilt University Medical School, Canby Robinson, wrote to the Rockefeller Institute Director of Laboratories (who was in actuality functioning as the overall director), Simon Flexner, noting that "clinical investigation has been rapidly developing in this country, largely due to the great impetus given to it by the Hospital of the Rockefeller Institute ... There is at present no journal properly expressing this important development in American Medicine. There is not only a great delay in publishing, but also a scattering of material into journals designed for other special groups of workers." Robinson went on to say that a new journal could "serve as a stimulus for the elevation of the standards of clinical investigation." If the Rockefeller Institute didn't want to publish such a journal, possibly they could support the ASCI to do so (25). When the Institute was slow to support the journal, Robinson again wrote to Flexner on March 25, 1924, to say that he had made inquiries to other publishers about publishing such a journal, including Williams and Wilkins and the University of Chicago Press (26).

Perhaps this letter stimulated the Board of Scientific Directors to come to a decision. On April 26, 1924, the Board decided to support a journal and recommended a yearly grant of $\$ 3,000$ to the ASCI, available for three years, "by which time it is expected that the Journal will be self-supporting." In a burst of optimism, the board stipulated that if the journal became self-supporting before then, the ASCI should not take the entire grant. The first issue of 
the JCI came out October 24, 1924, a new journal led by "new men, trained in a new way . . being supplied with new hospitals properly equipped with laboratories" (27).

JCI founders anticipated a flood of papers and an eager readership. But the reality of the first decade was far more sobering. Editors found themselves desperate for submissions. Alfred Cohn wrote a colleague in December 1925 saying that "We are much in need of material for the Journal of Clinical Investigation. The February number should go to press on January 1st and at present we have only two papers. I should be glad if you could direct any good papers to us" (28). The paucity of submissions forced the editors to publish a "large majority of the papers that had been submitted." Nor did the annual ASCI meeting supply the anticipated number of papers; only 10 of the 57 papers on the 1925 program were submitted. In 1927 the JCI was still accepting 71\% of the papers it received (29).

One response to the lackadaisical submission rate was to not commit to a set publishing schedule and to publish only whenever an adequate number of papers was in hand. This was not an unprecedented approach - the British physician Sir Thomas Lewis had originally adopted it for his prestigious journal Heart, which had started publishing in 1909. At one point, JCI editors decided "to continue issuing volumes at a rate depending upon the available material (600 pages per volume) not to exceed 2 volumes per year" (30).

Not only did they receive few submissions, but the demand for the JCI was far less than expected. Robinson wrote to Flexner after two years, in 1926, saying that they needed 1,000 subscribers to break even but had only 319 , lamenting that "the spread of the Journal has been very slow" (31). Even in these early days, some questioned the clinical relevance of JCI articles. As editors reported to the ASCI Council in 1930, "The recognition of the value of these articles by physicians at large in our country must inevitably, however, take much more time and can probably be expected only after the practical results of such studies become demonstrated." A flood of subscriptions from such physicians was unlikely to happen.

Who should bear the financial burden for this struggling journal? While the Rockefeller Foundation was willing to assume startup costs, foundation officials believed that universities needed to assume some of the ongoing costs, that "every university department should have an item in its budget for the cost of publication of research data ...” (32). In January 1928 the Rockefeller Institute provided the ASCI with a final installment for the JCI and advised the Council that further support would not be forthcoming.

The JCI was able to improve its financial situation. Although they did not formally budget for publication costs per se, about 15 university clinics signed up as associate members to provide a few hundred dollars a year. A dues increase for individuals from $\$ 3$ to $\$ 10$ per year garnered some additional funds, as well as providing each ASCI member with a subscription to the JCI. In 1930, just as the Great Depression was getting started, the JCI editor could report to Council that for the first time the journal was wholly supported by subscribers and university clinics.

But because university support was pledged on only a year-toyear basis, and because of a desire to improve business management, the ASCI approached the Chemical Foundation for support. The Foundation took over running the JCI on July 15, 1931, just as general economic conditions worsened. In 1933 the JCI had only 577 subscribers. Editors tried to increase subscriptions by mailing information to potential subscribers. This effort cost over $\$ 1,300$, yet in the face of the Great Depression yielded only three new subscriptions at $\$ 10$ each. The manuscript acceptance rate remained well above $50 \%$. The Chemical Foundation soon found itself subsidizing an annual deficit of almost $\$ 4,000$ per year (almost $\$ 70,000$ in 2008 dollars). They were no more sanguine than the Rockefeller Institute had been about remaining indefinitely the primary source of long-term support. According to the JCI editor, they "indicated to us that a journal to receive continuing support must be progressing towards a self-supporting basis. It is impossible to contend that under our present policies our journal is exhibiting satisfactory progress towards self-support." Self-support would require about 900 subscriptions, and the editor was pessimistic about getting there. "The practically complete failure of three vigorous advertising campaigns leads me to infer that it is useless to expect the necessary increase in subscriptions." He outlined the options. The ASCI could drop the price to $\$ 4$ per year and hope to get 2,500 new subscriptions. They could attempt to broaden the journal's appeal by adding review articles. They could institute page charges, publish only abstracts, or improve management. Or, once bank reserves were exhausted, the JCI could simply cease publication sometime around December 1935. In other words, in the mid-1930s, the editors seriously considered the possibility that the journal might fold (33).

But somehow, the editors managed, barely, to keep the journal intact until economic conditions improved. One editor reflected "That a journal should survive its preliminary stages must often have been a source of wonder to its sponsors ... The Journal has never been prosperous in any ordinary meaning of the word. Its financial life has always been precarious" (34). The Chemical Foundation eventually withdrew support in 1940, but by then the JCI was well-enough established to carry on.

\section{Science becomes noticed}

During the interwar years, the annual ASCI meetings started to be seen as important news events. In 1926 the New York Times noted that the ASCI meeting would be "turning the Hotel Traymore into a clinical laboratory” (35) (Figure 5). Sometimes reporters covered scientific studies that we would now see as progressive, such as using radium to measure blood velocity; other times they covered

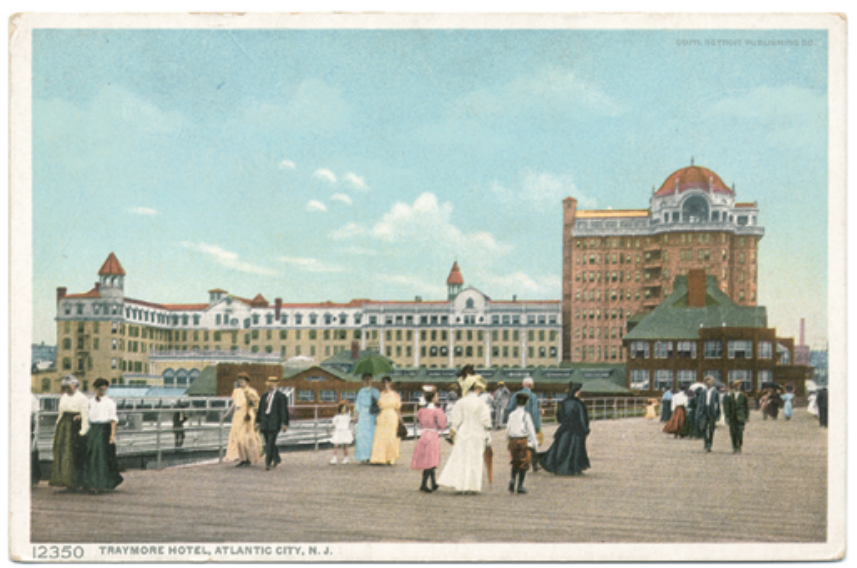

\section{Figure 5}

The Traymore Hotel was the site of many $\mathrm{ASCl}$ meetings in Atlantic City. The ASCl no longer meets in Atlantic City, and the Traymore Hotel was demolished in 1972. (Reproduced with permission from the New York Public Library.) 


\section{Figure 6}

During World War II, the role of physicians and of medical research was redefined. Medical research was widely supported in areas including the development of new vaccines to prevent typhoid and epidemic typhus. After the war, federal support for research dramatically increased. (C Corbis.)

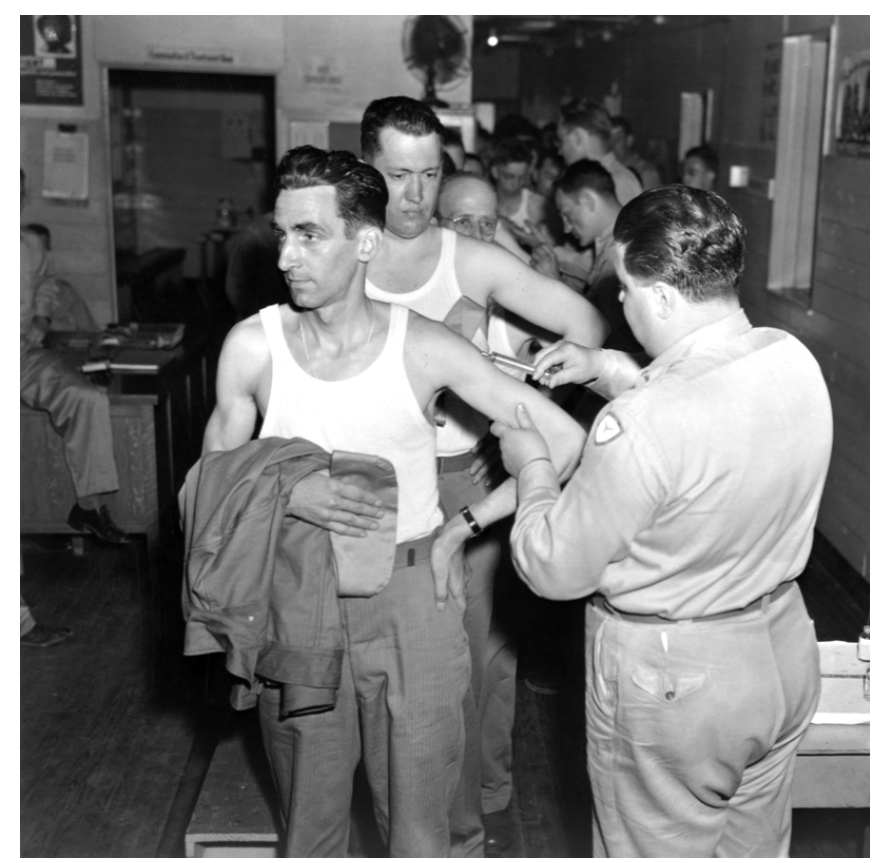

parts of the world" and "An unknown number of copies have gone to the bottom of the ocean," JCI editors anticipated the need to reprint back numbers after the war.

\section{A new model for research funding}

When peace finally came, it was clear that scientific research had played a major role in determining the victor (Figure 6). This was true most obviously for the physical sciences, which developed radar and the atomic bomb, but it was also true for the biomedical sciences, which developed blood banking techniques and the mass production of penicillin. But in terms of the impact of the war on medical research, arguably even more important than the wartime scientific advances was a transformational set of organizational decisions that would shape the next 50 years of biomedical research (and beyond). The ASCI and its members reflected and debated these decisions and wound up benefiting beyond their wildest dreams from this radical change in the support of scientific research.

Prior to 1940 , the federal government supported very little biomedical research, almost all within federally run institutions. But from early in the Second World War, it was clear that science would play a major role in the war's outcome, that the federal government would need to support scientific research, and that existing federal laboratories lacked sufficient capacity. Therefore, in 1941 the Committee on Medical Research started supporting research projects all around the country. And, given what amounted to a direct presidential mandate and virtually unlimited funds, they funded generously. Scientists became accustomed to having ample resources for whatever they needed to do. This was a new way of doing research, and one to which scientists found it easy to adapt. Clinical researchers produced impressive results on topics such as antibiotics, adrenal steroids, and blood plasma. Congress saw these results as an impressive harbinger of what biomedical researchers could accomplish if only given adequate resources (42).

Funds were provided through the mechanism of research contracts, which had clearly defined objectives and required quarterly financial and scientific reports. Until 1944, the Public Health Ser- 
vice (PHS) lacked legislative authority to award extramural grants. But the PHS Act of 1944, little noted at the time, authorized the Surgeon General, rather than relying only on contracts, to "make grants in aid to universities [and] hospitals ..." After the war's end, 44 research contracts were transferred to the PHS (43). Many of those projects used the newly available antibiotic penicillin. Because the cost of penicillin was rapidly falling, additional funds became available, and in 1945 the PHS advised medical school deans that they could submit letters asking for additional research support. With this rather indirect approach, a system of extramural PHS research grants came into existence.

It was hardly the federal research system envisioned by Vannevar Bush, who had directed the wartime Office of Scientific Research and Development. In a report for President Franklin Roosevelt, Bush advocated a massive increase in postwar federal research support. He argued that "basic scientific research" was essential for national security, economic growth, and the very values on which the United States was based. As we could no longer depend on "ravaged Europe as a source of fundamental knowledge," Bush proposed a single overarching national research foundation that would encompass all forms of scientific research, including medical research (44). However, for a variety of political reasons, that agency, the National Science Foundation (NSF), was not created until 1950. By then, the extramural PHS program was already so well established that the new NSF decided to leave biomedical research funding to the PHS $(45,46)$.

PHS extramural funding grew more than ten-fold in the first four years after the war and continued to grow rapidly thereafter. Faced with decisions about how to distribute these funds, the PHS invented now-familiar systems. They appointed civilian consultants to "study sections" to advise about grant funding. Diseaseoriented institutes were established, and the grant-making structure reflected those divisions. The funding system has continued in basically the same form to the present day, albeit at a scale that likely would surprise even the most ardent advocate in 1945.

ASCI members flourished in this new system. However, as natural as the grant-making system may seem in 2009, it was initially quite controversial. Logical, rational opposition was raised to federal support for research. The main questions were whether the risks outweighed the benefits and whether funds ought to be allocated to individual investigators or to some larger unit.

Thomas Francis titled his 1946 ASCI presidential address "Biological Beachheads," doubtless with some thought to the recently ended conflict (47). He was skeptical about creating a new national agency for research support because "Administrative principles of a large organization tend to be founded on orthodoxy." Rather than having investigators waste time and divert their attention from important scientific work in order to seek funds, he thought it better to have general research funds distributed through universities. Francis warned about the "red tape of premature accounting and justification" and about the role of lobbying and pressure groups. But at the root of his and others' concerns was an arguably even more serious set of issues. The medical research atrocities committed in Germany during the war were starting to become widely known. Many of these atrocities had been committed by extremely distinguished physicians, clinical scientists who prior to 1939 would have been considered among the very best in the world. How, Americans wondered, could such distinguished physicians have committed such heinous acts? The answer was thought to lie, in part, in the govern- ment support of their research. The events in Germany were thus seen as an example of what could happen when the government gets involved in research support.

But confidence in the ethical sensibilities of American clinical scientists combined with the promise of readily available funds quickly overcame such concerns. In October 1949, ASCI member John H. Dingle, recently named head of preventive medicine at Western Reserve University, wrote to incoming ASCI president Thomas Hale Ham (of the Ham's test, the definitive test for diagnosing paroxysmal nocturnal hemoglobinuria [PNH]). Dingle had represented the ASCI on the National Research Council and had already advised the ASCI Council to take more interest in the workings of federal support. In his letter to Ham, Dingle shared concerns that the widespread provision of federal research grants meant the "possibility of governmental control and ultimate political domination" and that "control of funds may be in the hands of a small number of individuals who might thus acquire tremendous power." However, he made the prescient observation that the ASCI "must accept the reality of government funds for research and education," for "governmental funds, chiefly federal, as a means of support of research are of great importance and probably will continue to be so" (48). Ham was to warn the next year of the dangers of choosing a research problem based on ease of financial support, and especially of politics (49).

But before long, the question about whether government funds were to support research had been answered in the affirmative. The question remained (if only for a while): How? Funds might have been awarded to the promising investigator absent any specific research plan. This method could avoid what some ASCI presidents saw as the "wasteful expenditure of large sums of money" on the assumption that "scientific knowledge can be bought"; the money would be better used not for specific research projects but to fund individual endowments, offered to "the man and not the project" $(50,51)$. Another possibility, one that was for a time close to the standard, was for funds to be given not to the investigator, but to the university or to the head of a unit. In 1948, JCI editors could still assert that "It is taken for granted that the head of a department is responsible for acquiring the funds for a particular study" (52). But the burden soon shifted from department heads to laboratory directors, who took the first steps toward becoming administrators and grant-getters. By 1956 ASCI president A. McGehee Harvey lamented that older investigators do not spend enough time in the laboratory. His solution was more federal money for unrestricted general support and less for categorized research (53). Albeit more for categorized research than for general support, federal funds kept on flowing.

\section{Glory years}

The 1950s marked the start of "American Medicine's Golden Age," and the ASCI was very much a part of it (54) (Figures 7 and 8). The spigots of NIH funding opened ever wider; many new medical schools were opened; rapidly expanding Veterans Administration hospitals and laboratories offered new opportunities for research and training; and the public's already high opinion of physicians became even higher (55). The public read about ASCI meetings in glowing terms: "Researchers Cite Medicine's Gains," read one headline, followed by an opening sentence stating that "Medical researchers had a field day against disease and infirmity ..." as they heard reports that "delineated the frontier of medical science today" (56). Perhaps the height of praise came in a 1952 Time mag- 


\section{Figure 7}

The postwar research environment came to be dominated by the increasing use of new, complex laboratory technology, such as this mass spectrophotometer. (Courtesy of the National Library of Medicine.)

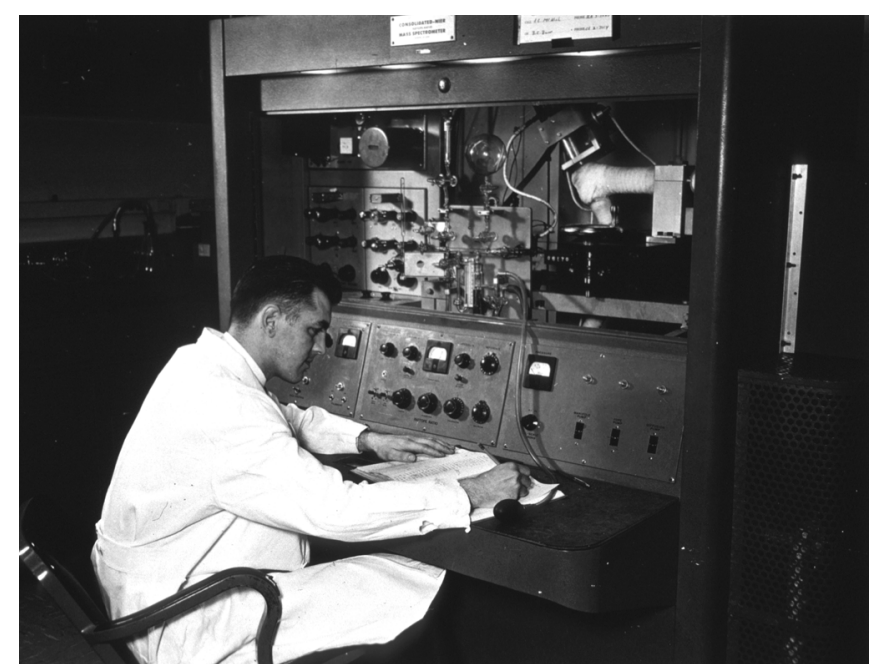

and speed of travel and the availability of funds to support it has led to such a massive proliferation of meetings, conferences, and symposia that one wonders when the participants will find the time to get any new work done" (61). ASCI meetings grew enormously. These meetings had long been held with the AAP; with the addition of the American Federation for Clinical Research (AFCR, created in 1940, which changed its name to the American Federation for Medical Research [AFMR] in 1996), the so-called Tri-Societies meetings came routinely to draw combined attendances in the several thousands.

As a result, in 1950 the meetings moved from a relatively small Atlantic City hotel to the Steel Pier Theater and a much larger auditorium. While the new site allowed more trainees to be inspired by the academic elite's presentations, some members complained that the meetings had become too large, too crowded, and the discussions less intense and less productive. Nonetheless, these large meetings became the defining events of the academic year. Trainees were expected to go. Physicians made long-lasting reputations and secured excellent jobs based on their ASCI presentations. The most exciting research of the year was presented there; "medical history was being written" $(62,63)$.
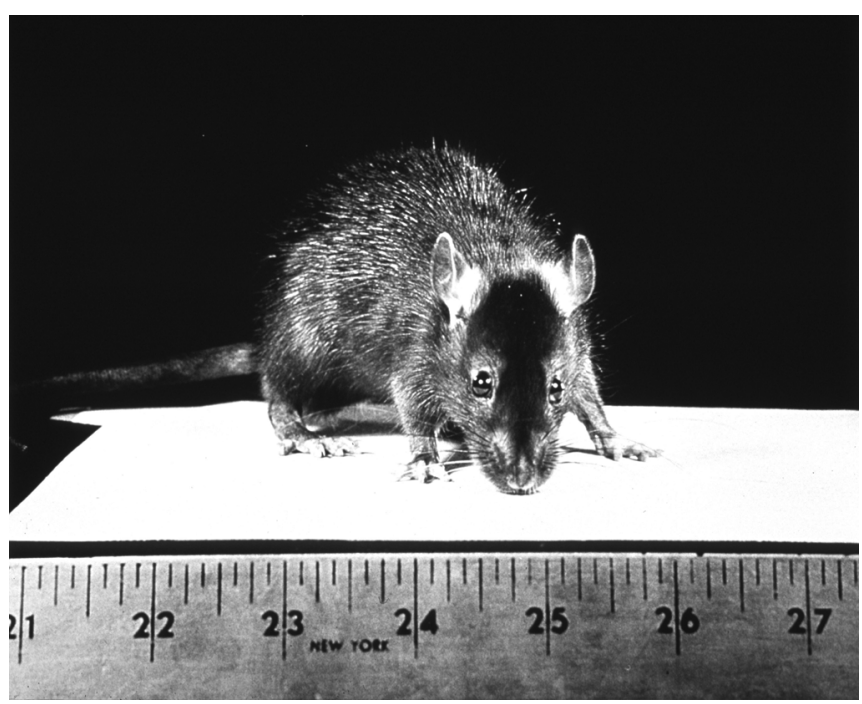

\section{Figure 8}

As federal funding for laboratories expanded, more and more of ASCI members' research came to be done not on human beings but on laboratory animals, such as this Norwegian rat in a photograph from the 1950s. (Courtesy of the National Library of Medicine.) 
As the meetings grew, they became more formal. ASCI members sat in a special roped-off section, first formally noted in the 1941 program, "where the lions of academic medicine were loosely caged" and were the only ones allowed to ask questions (64). Eugene Braunwald has provided a vivid description of the attendees: "Virtually all who strolled by, regardless of age, were white males, usually with closely cropped hair and wearing a standard uniform: white shirt with button-down collar, striped tie (black and dark green were the favorites), charcoal gray slacks, herringbone jacket often with leather elbow patches, and well-shined black shoes. Almost all ... were pipe smokers" (65).

In 1959, as the ASCI celebrated its 50th anniversary, the future appeared secure for the values that the ASCI advocated (66). Federal support for clinical research was no longer seen as something to be debated. Rather, the public had come to believe that "their future depends on scientific research," and public funding, rather than being controversial, was thought to be virtually guaranteed (67). Over the preceding 20 years, federal grants for medical research had risen from $\$ 40$ to $\$ 700$ million per year and had become the dominant source of support for medical research (68).

\section{Controversy in the Golden Age}

Yet all was not rosy. Some rough spots might have seemed foreseeable to those who earlier had warned that federal research funding could be used as a political tool. ASCI members confronted the Cold War bigotry of the McCarthy era. Laboratory directors were pressured to fire staff who belonged to the wrong type of organization (69). ASCI members were dismissed from study sections after anonymous accusations of disloyalty (70). Grant funding could be used as a tool for political pressure, leading ASCI members in 1955 to send the following statement to the secretary of Health, Education, and Welfare: "We ... are greatly perturbed by your recent announcement that competent investigators have been deprived of USPHS research funds because of allegedly derogatory information in their files. We recognize the need for security clearance of individuals engaged in classified research. However, it is our firm belief that awarding grants for unclassified research on any basis other than the value of the project and the competence of the investigator endangers not only scientific freedom but also the very foundations of our way of life." During the Cold War, the spread of science was increasingly restricted by ideological pressures; while the JCI once had more than 100 subscribers in China, by 1956 it had only two.

The ethics of clinical research was thrust into the spotlight with ASCI member Henry Beecher's landmark 1966 New England Journal of Medicine article "Ethics and Clinical Research," in which he described serious ethical issues in 22 experiments (71). Though the experiments were not specifically cited, Beecher's examples were prominent enough studies by distinguished enough clinical scientists that contemporary readers had little doubt as to the identity of many of the investigators (72). Of the 22 papers, at least seven had authors who were ASCI members, and three had been published in the JCI. Beecher's article sparked a flurry of national attention. An ASCI committee met with representatives of several other major societies to discuss the 1964 Declaration of Helsinki, a statement of ethical principles proposed by the World Medical Association. The ASCI endorsed the Declaration and published it in the JCI (73). In 1967 ASCI president Grant Liddle devoted his address to the ethics of clinical investigation (although he preferred the term "mores") and to the Declaration of Helsinki, giving a detailed analysis of why and when informed consent might come into conflict with other principles (74). Liddle also suggested that clinical investigators ought to form a moral community with its own responsibility for enforcing a code of conduct. Although he did not mention Beecher explicitly, it's hard to believe that Liddle's talk was not in some important ways a response to Beecher's exposé.

The 1960s were turbulent times. In his 1964 presidential address, Irving M. London noted the "revolts of the colored peoples of the world against deprivation and indignity" (75). Meanwhile, the US military was moving ever more deeply into a controversial conflict in Southeast Asia. In 1970, as conflicts over the Vietnam War convulsed American society, the controversy spilled over into the Atlantic City meetings. ASCI member Kurt Hirschhorn proposed that the following message be communicated to President Richard Nixon: "The American Society for Clinical Investigation condemns the increasing US military involvement in Indochina because of its destructive effects on the health and welfare of the people of both the United States and Indochina. We believe that the funds expended for this effort would be more beneficial if used to improve the health of both peoples. We therefore urge you to reverse the recent decision increasing the scope of US military action in Indochina." This resolution was put to a secret ballot - not on whether the members agreed with the expressed sentiment, but on whether to send this message to Nixon. The vote was 102 to 150 against sending the message. However, this vote made it clear that a significant proportion of the voting membership wanted the ASCI to take a public stand on at least some national policy issues. The question of ASCI involvement in policy discussions was to come up again.

The upheaval over Vietnam was soon followed by debacles such as the Watergate scandal and the Three Mile Island accident, leading to increased public distrust of many previously respected institutions. Concerns about science were fueled by a few prominent instances of fraudulent scientific research, some presented at the ASCI annual meeting. One of the most prominent examples was offered at 2:00 on the afternoon of Monday, April 30, 1973, with the auspicious title of "Successful Tissue and Organ Allotransplantation without Immunosuppression.” The results were so striking that the author was given a prolonged standing ovation (William N. Kelley, personal communication). This may have been the only such standing ovation ever given at an ASCI presentation. Unfortunately, the results were found all too soon to be invented (76).

Worried that the handful of known fraudulent cases was merely the tip of the iceberg of a much more systemic problem, the US Congress held hearings in 1981 on publication of fraud in biomedical research (77). Chaired by Representative Albert Gore Jr., the hearings attracted widespread attention $(78,79)$. The JCI became a prominent part of the public discussion because one of the fraudulent cases investigated by the committee had appeared in the JCI. When the article's senior author became aware that the work was fraudulent and wanted to publish a retraction letter, the editor refused to do so because the JCI had a "tradition of publishing only original scientific work" (which had been a point of pride at the 50th anniversary) and had never before had a correspondence section. The JCI editor's letter of May 28, 1980, refusing to publish a retraction was included in the Congressional report as well as being quoted in the New York Times. The JCI's position received no support; most felt that the recent revelations of misconduct precluded a "business as usual attitude." 
The JCI soon broke with its previous tradition and started publishing retractions (80). The issue of fraud was salient enough to be the topic of the next year's ASCI presidential address by Philip Majerus (81). In his years as JCI editor (1977-1981), Majerus said that he saw dozens of examples of inappropriate data interpretation but found only two cases of fraud. Unfortunately, the JCI was once again in the national press over fraudulent articles only a few years later (82). Issues surrounding appropriate publication continue to arise, albeit with a more open discussion than had been the case in the 1980s (83).

\section{"The centre cannot hold"}

Throughout the 1960s and the 1970s, the combined spring meetings of the ASCI, AAP, and AFCR were the jewel in the crown of the academic clinical researcher. A presentation there could be recalled later as the key moment in an early career (84). Yet the glory years could not continue. The days of the 3,000- to 4,000-person megameetings were numbered. The precise turning point is hard to say. Perhaps it was about the time the meetings left Atlantic City, in 1977. Perhaps it was 1985, when the number of submitted abstracts started to fall. In any event, the decline, when it came, was rapid. The number of abstracts had fallen by almost half in 1992, and by 1996 attendance had fallen by a similar percentage $(85,86)$.

The demise of the mega-meeting had several interrelated causes. One was the same efficient transportation that had enabled its rise only a few decades before. Just as airplanes could carry an investigator across the country to the spring meetings, airplanes could just as easily carry that same investigator somewhere else. Previously, traveling overnight (or two nights) on a train represented a significant time investment and encouraged travelers to settle in for an extended stay. No more. Now, air travel made it easy to travel and return in a single day. Professors found themselves flying around the continent year-round to give seminars, to collaborate, to consult, and to engage in the sorts of face-to-face interactions that had previously been the unique staple of the spring Atlantic City meetings. Junior scientists were less likely to travel than their senior mentors, and the demise of the meetings meant they experienced less of the informal, cross-institutional mentorship that previously had been obtained on a walk down the Boardwalk.

Just as the airplane could take someone to visit another institution, so, too, it could take someone to attend a different meeting. Probably the most important single factor in the demise of the Tri-Societies' mega-meeting was the inexorable rise of medical specialties and subspecialties. This change had been a long time coming, and it did not come easily. The clinical researchers who had created the ASCI espoused an aggressively generalist style, actively opposing any hint of specialization. Consider the intensity of Alfred Cohn, an early ASCI member based at the Rockefeller Institute. Cohn was a leading ECG researcher and highly respected expert on heart disease. Yet he railed against the very existence of a special journal on heart disease: "I am quite frankly opposed to the founding of journals devoted to the study of specific viscera. It seems to me that the study of heart disease from 1909 onward [the founding date for the journal Heart] lost a great deal of significance on account of its divorce from the main current of clinical medicine while the study of medicine itself was deprived of proper contact with the development of knowledge in this field by publishing good things in separate journals. In a sense the tendency is created for fellows who work on heart disease to study no other journals ..." (87).
Cohen's concerns notwithstanding, the field of cardiology and its journals continued to grow. At least for a time, cardiology remained firmly imbedded within internal medicine (although cardiology fellows doubtless gravitated to reading heart disease journals). And it is internal medicine that has long dominated the ASCI, though membership is open to all specialties. (Consider that the other name considered for the 1916 name change was the "American Society of Internal Medicine.")

Prior to the Second World War, it might have been possible to hold fast to the belief that internal medicine could continue as a single, unified specialty. During the war, the Army's Medical Department emphasized specialty care. Given the massive size of the Medical Department and the numbers of physicians involved, the Department provided a big impetus toward the dominance of specialty and subspecialty medicine (88). After the war, the nascent cracks between subspecialties started to become too obvious to ignore. New specialties arose, based increasingly on the new technologies that were coming to dominate and define biomedical research. ASCI president Carl V. Moore noted the tendency of modern laboratories to have "more pieces of equipment than ideas" (89). New specialty boards were formed. In 1952 ASCI president W. Barry Wood made the prescient observation that specialization is here to stay (90).

Yet for a while, internal medicine departments did not embrace subspecialization. The average department size in 1957 was a scant 15 faculty members, a group small enough to easily remain unified. Even as NIH funds continued to grow exponentially, department chairs remained generally oblivious to the upcoming explosion that would make a unified department difficult to maintain. Chairs in 1957 hoped that 15 years hence, in 1972, department size would modestly increase, but only to 32 faculty members (91). The actual increase in departmental size was not imagined by "anyone in academia," even by those at the most prestigious schools (92). In fact, surging NIH funding led to not only larger but also more subspecialized departments with larger and more autonomous division, especially cardiology, gastroenterology, and hematology (93). As internal medicine subspecialties grew, they assumed the usual trappings of a separate specialty: journals, certification, reimbursement, and, most important for this discussion, separate meetings. As departments of internal medicine became ever bigger (even by 1972, a department of 32 would have seemed small), there was less communication between divisions, less interest in being a single, unified group. Internal medicine departments became fragmented based on topic, on size, on earning power $(94,95)$. Subspecialties became the center of the academic universe, and the number of attendees at subspecialty meetings swelled to as many as 30,000 . Faculty and trainees increasingly went to such meetings to present the newest, hottest research results.

What was to be done with the ASCI meeting? Except for a couple of wartime years (1943 and 1945), there seems to have been a consistent consensus that an annual meeting ought to be held. Debates about the form and content of the annual meeting have been a constant almost since its inception. Should there be a twoday session? Rejected in 1921. Should there be an evening session? In 1932 this question was raised - and after considerable debate, the answer was no. Should there be separate, specialized sections during the annual meeting? Sometimes, but not usually. These scheduling experiments were dismissed in favor of plenary sessions, in the name of unity, in the belief - usually valid in the prewar era - that members would want to remain current across the broad swath of disciplinary perspectives. 
Should ASCI meetings always be held in the same place? Starting in 1933, the ASCI met in Atlantic City for many years, but not without discussion of change. The 1954 Council noted that always meeting in the same place causes "disadvantages and inequities to a large segment of our membership and guests" and the next year noted that "the society will continue active [italics in original] exploration of the possibility of meeting occasionally in a city other than Atlantic City." But it would be 1977 before the meeting left Atlantic City and moved to Washington, DC, starting what ASCI president Laurence Early called an "annual sojourn around the continent" with the sister societies (96). As attendance dropped and the most exciting scientific findings moved to subspecialty meetings, there was no longer the need or the desire for the same type of massive Tri-Societies meeting. In 1998 the ASCI held its final meeting with the AFMR. After the breakup, there were some attempts made to reproduce the spirit of a joint meeting with other clinical groups, none with significant success. The meetings today are held with the AAP and are focused on longer, thematically linked talks by distinguished scholars. The question as to what sort of annual meeting to hold has been a constant debate over the ASCI's history, and it will doubtless continue.

\section{Continuity and change: who should be a member?}

ASCI members have had to answer many other questions over the past century. While the questions may not change, the answers have. Or not. Some questions raised over the course of the century have been essentially resolved - should physicians do clinical research (yes), should the ASCI formally sponsor local societies (no), should the association publish a journal (yes), should its members rely on federal research funds awarded on the basis of individual research grant applications (yes). These were all questions that could have been answered differently. On the other hand, debates over some core questions have persisted over many decades.

One of the most fundamental questions for any organization is simply this: Who can be a member? The ASCI was founded by physicians, for physicians. But what about people doing what is clearly clinical research of the highest quality but who do not hold an MD? This question was called early on for a very high-profile candidate.

In 1924 the ASCI decided not to admit the Toronto physiologist J.J.R. MacLeod. This rejection was special enough (indeed, it seems to be unique in this regard) that the Council instructed the secretary to write a personal note to MacLeod "expressing the regret of the society that not without modification of the Constitution of the Society would it be possible to add his name to the list of members." For MacLeod was no ordinary nominee. Along with the surgeon Frederick Banting, he had discovered insulin, one of the most dramatic and important medical discoveries of the 20th century. Soon after the discovery, there began a life-long controversy over who deserved credit, a controversy only heightened after the 1923 Nobel Prize in Medicine or Physiology was jointly awarded to Banting and MacLeod (historical scholarship has made it clear that both were undoubtedly worthy of the prize; ref. 97). MacLeod held a PhD, but no MD. As accomplished as MacLeod was, and as important as his discovery was, there was to be no wiggle room on the requirement that members be physicians. Even if he be a Nobel laureate, MacLeod could not be an ASCI member. Banting, on the other hand, was promptly honored with ASCI membership upon his initial nomination in 1924.

The MD requirement has persisted, although another original membership requirement has gradually slipped away. Early on, the ASCI was quite explicit that members needed not only to hold an
$\mathrm{MD}$, but also to be active, practicing clinicians. On more than one occasion the Council, not wanting to elect someone who was "not primarily interested in the clinical branch of medicine," asked the secretary to explicitly seek assurance from nominators that a candidate was engaged in active clinical practice (ref. 16, pp. 225; and ref. 98). Over the years, this clinical practice requirement gradually disappeared without any formal debate being recorded. By the time Henry Kunkel gave his 1962 ASCI presidential address, "The Training of the Clinical Investigator," it was clear that many ASCI nominees had little, if any, regular contact with patient care (99).

As "clinical research" moved farther from the bedside and closer to the laboratory bench, it became increasingly apparent that the research being done by people holding MDs and people holding PhDs (but no MDs) was often very similar. In 1979, dropping numbers of nominees led ASCI president Kenneth L. Melmon to consider whether the ASCI ought to admit PhDs (100). In 1993 an ASCI committee explicitly addressed whether non-MDs ought to become eligible for ASCI membership and concluded that they should not. Instead, they suggested, PhDs could become honorary members. Further discussion revealed some strong voices in favor of allowing PhDs to become regular members. The JCI editorial staff liked the idea, feeling that it might increase submissions from PhDs. Witnessing a decline in interest and nominations, some went so far as to suggest that admitting PhDs "might save the society from eventual extinction." It was noted that clinical specialty groups treated non-MDs as equals. Some suggested that the current practice led to a double standard - PhDs could give plenary talks yet couldn't be members. Those in opposition to changing the basis for admission noted that allowing PhDs would lead to more work for the Council and, perhaps most significantly, could change the ASCI character. After a 1997 survey showed only $5.7 \%$ of ASCI members in favor of electing non-MDs, the matter appears to have largely died down.

America has long grappled with the issue of women in medicine. Only in 1849 did Elizabeth Blackwell become the first woman to graduate from a US medical school; in 1870 the University of Michigan became the first major medical school to admit women. During the early 20th century, a few women gained admission to many formerly all-male medical schools, yet as previously all-female schools closed, the numbers of women in medicine declined (101-103). Prominent leaders discouraged women from entering medicine, including Yale's Medical School dean and ASCI president George Blumer. In his nationally noted 1918 address, "Medical Education in Relation to the War," Blumer, concerned about the toll the First World War was taking on medical school faculty, feared that "the decimated ranks of teachers must be filled by women, cripples, and dotards" (19). By explicitly linking women with "cripples and dotards," he was clearly stating that he did not see women as desirable members of the (or his) medical school faculty. (Nonetheless, Yale was among the leaders during this period in training women scientists; ref. 104.) That Blumer chose to make his remarks just as women were trying to gain the right to vote (which they did upon the 1920 ratification of the 19th amendment to the US Constitution) was doubtless not lost on his audience.

During the first part of the 20th century, only a few women were elected to membership in the ASCI, in modest numbers that mirrored the general difficulty women had in succeeding in any medical or scientific field. The situation started to change following the early 1970s passage of "equal opportunity" amendments to the Civil Rights Act, as female applicants to medical school 
more than tripled. In 1976, the Association of American Medical College data directed attention to the gender gap in US medical school faculties. In this climate of increased attention to women, ASCI member Phyllis Bodel urged the Council to try to increase the nomination and election of women. Bodel was a Yale internist who strove to improve professional opportunities for women both locally and nationally; she died from leukemia only one year after meeting with the ASCI Council, at the age of 44 (105). After her meeting with the Council, the numbers of women admitted to the ASCI started to increase. During the years 1969-1978, only $2.4 \%$ of people elected to ASCI membership were women. That percentage nearly doubled over the next ten years, to $4 \%$. Today, as the ASCI reaches the end of its first century, while medical schools are approaching a 50:50 gender split, only about $15 \%$ of those elected to ASCI membership are women. One obvious route to future ASCI membership is through medical scientist training programs. They are nearing a 50:50 gender divide, albeit more slowly than medical schools at large. However, there is greater attrition for women than men in these programs, and the number of women in senior positions still lags (106-108).

The initial ASCI members were quite young, many in their early thirties. Election to ASCI membership has been restricted to people under the age of 45 . Suggestions have been made both to lower this age requirement and to raise it; the latter suggestion is based in part on the fact that some physician-scientists have career tracks that are interrupted by family obligations, and those people are disproportionately women. Despite several formal reviews of the age requirement, it has not been changed. In 1930, the ASCI decided that members who reached the age of 45 would become emeritus. Today members acquire senior status at age 51 and are eligible for emeritus status at age 65. The intent has remained the same, that the society be made up of relatively young members.

We do not have reliable data on ethnicity and ASCI membership, but it is unlikely that the ASCI has been any better than medical school faculties at large in recruiting members of underrepresented minorities. In 2002, only 6\% of those receiving PhDs in the biomedical sciences were from underrepresented minorities (109). Other criteria once used for membership have largely disappeared. For many years, prominent medical schools used quotas to cap the number of people with specific religious or ethnic backgrounds $(110,111)$. As late as 1939, T.R. Harrison noted in his ASCI presidential address that religion was often used as a marker for appointment to societies and academic posts (112). On the whole, the ASCI has probably mirrored the larger profession in accepting non-majority members.

While a history of the changing scientific methods that have been used to advance "clinical research" lies beyond the scope of this article, a persistent question for the ASCI has been whether nonbiological research ought to qualify someone for membership. Recall Haven Emerson, whose 1909 scientific presentation, the very first ever to an ASCI meeting, was based on a high-technology diagnostic tool. Emerson was a leader in the small group of physicians who were shaping remarkable changes using experimental physiology to study medicine. However, by the time Emerson became ASCI president in 1917, he was New York City Commissioner of Health and had turned his scientific research interests away from the bench sciences to public health and epidemiology. His 1917 ASCI presidential address, "The Community as a Patient Needing Clinical Investigation," reflected his shift in research focus and may mark the first intimation of serious population- based research in the ASCI. Emerson went on to a distinguished career as an epidemiologist, a founder of the American Epidemiological Society, and a president of the American Public Health Association (113-115). While his turn to a population-based research model might later be seen as suggesting a public health orientation, in 1917 the gap between public health and medicine was much smaller than it is today, and this sort of research was well accepted in the medical school world (116).

In 1938 John Paul, a distinguished scientist who provided fundamental insights into poliomyelitis, devoted his ASCI presidential address to the subject of clinical epidemiology, which he saw as "a new science... in which this new Society might take an important part." Paul pleaded for the ASCI to take a broad view of research methods: "Of late years conservative opinion does not allow anything to be really considered as 'etiology,' unless we can succeed in getting it into a test tube, unless we can precipitate it - unless we can crystallize it as it were. This is due of course to our current methodology which has, perhaps, become more of a religion than most of us realize. I think it may have led to a slightly narrower interpretation of clinical investigation on our part, for clinical investigation certainly should be given the opportunity to spread itself up into philosophy, if it will, as well as down into the basic sciences" (117). A few years later, the editors of the JCI agreed with Paul, decrying the cult of the new scientific tools and wishing for a new emphasis on "emotional, social, and economic factors in human sickness” (118).

Voices calling for a more catholic interpretation of the meaning of clinical research were largely washed away by the postwar torrent of NIH funds and the demonstrable achievements of the basic biological sciences. During the latter half of the 1960s, health services research became a more established investigative method. In 1971 ASCI president Halsted Holman recognized the "importance of rigorous and imaginative research and experimentation in health care delivery" and proposed that the ASCI establish a regular section as a way to foster such research.

It didn't happen. Some members were not so sanguine as Holman about accepting ASCI members based on nonbiological research. Compared with the traditional sciences, health services and outcomes research could be seen as less scholarly and more ideological. In the turbulent 1970s, members feared that people working in these fields would politicize the ASCI. Another issue was how to judge the quality of nonbiological research, since most ASCI members were unfamiliar with its techniques. One suggestion was an ad hoc committee to review such applicants, but others feared that such an approach could be the "camel's nose under the tent," leading to an organized constituency that might eventually become a dominant force in the ASCI. In 2001 ASCI president David Ginsburg suggested that one way for the ASCI to acknowledge the different scholarly traditions was to reorganize into two sections - one laboratory based, one not (David Ginsburg, personal communication). This suggestion was not acted on. Today, the ASCI admits a few members based on nonbiological research, but the vast majority continue to do clinical research using methods drawn from the laboratory-based sciences.

\section{Continuity and change: what should the ASCI do?}

Should the ASCI do anything besides its original goal of selecting new members and holding an annual meeting? Answers to this question have varied throughout the years. The ASCI has occasionally attempted some sort of outreach. From 1991 to 1997, 


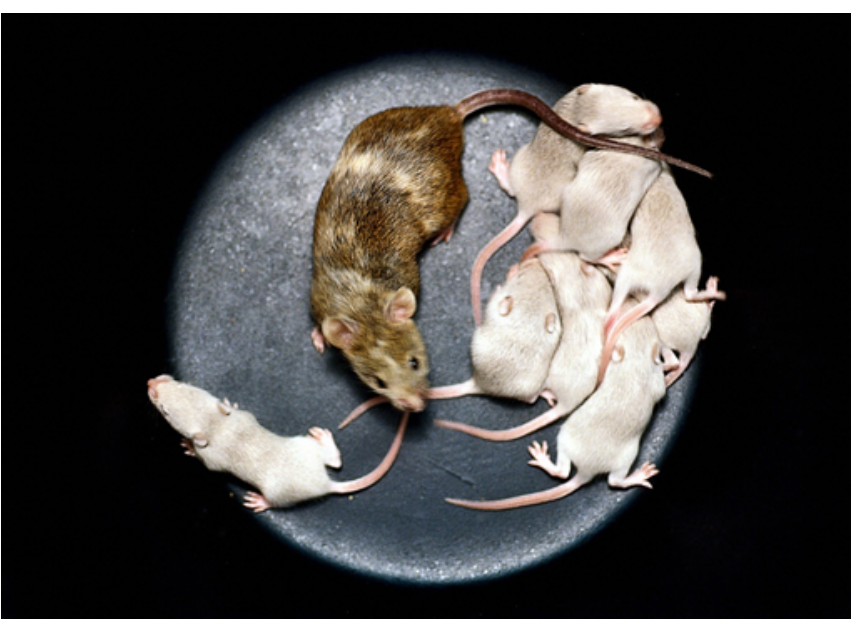

it offered a program designed to give high school teachers the chance to spend time in a science laboratory, but it discontinued support because the program was not seen as central to the ASCI's goals and objectives.

Ever since 1924, publishing the JCI has been one of the ASCI's most important activities. After surviving the difficult first few decades, the journal has prospered, in large part because it has embodied elements of both continuity and change. Research reported in the JCI has reflected the latest trends in biomedical research. A detailed content analysis lies beyond the scope of this paper, but a retrospective on the occasion of the JCI's 80th anniversary includes commentaries on notable publications $(119,120)$. Since the JCI has sought to publish original, innovative papers, it is perhaps not surprising that some medical practitioners have questioned the relevance of those articles for clinical care. Nor are these concerns new. The plaintive comments that "there is nothing very clinical about the JCI any more" have been heard for more than half a century $(121,122)$. Currently, about one of three of JCI papers accepted or returned for revision reports work done with humans or with human tissue - whether this percentage is too high, too low, or about right will depend on the reader's perspective (123).

The JCI's editorial staff and institutional home now move every five years. These moves have offered the opportunity for change. At its most recent editorial transition, the JCI named an associate editor who focuses on clinical epidemiology. Relatively new sections include editorials, book reviews, review articles, and, most recently, a section on "Technical Advances." The journal has itself embraced technical changes, although in 1977 color photography was only adopted over the objections of an editor who initially thought the idea "outlandish" (124). In 1996 the JCI became the first major scientific journal to be available free on the Internet, and in 2004 the layout was redesigned to be more useful for the increasing number of readers who read the JCI only on the Internet (125). After a rough start, the JCI does well enough financially to be a source of support for ASCI activities. The JCI has been selfpublishing since 1999. Its climbing impact factor (less than 11 in 2001, now over 16) reflects the high standing in which it is held. Joseph Goldstein and Michael Brown aptly described the special importance of the JCI - its readers are a broad group (broader than the readership of most specialty journals) but also a group more attuned to clinical relevance than most readers of other high-profile general scientific journals (124).

\section{Figure 9}

New tools and technologies have come to replace those of a century ago. This chimeric male knockout mouse is shown with its offspring. (@ Jenny Nichols/Wellcome Images.)

A final set of questions revolves around whether the ASCI should try to influence policy. Initially, the question seems not to have been explicitly asked, and the ASCI simply took a policy position whenever a majority of the members wanted to do so. For example, in 1917, as the United States pondered a constitutional amendment prohibiting the sale of alcoholic beverages, the ASCI weighed in on this important issue by passing a resolution saying "That in the critical condition of the world's food supply, we consider it desirable that the manufacture of alcoholic beverages or their importation into this country be prohibited for the duration of the war and for at least one year thereafter." (Available records do not document whether there was a significant reduction in the consumption of alcoholic beverages at ASCI meetings after passage of this resolution or after the 1919 ratification of the amendment.) Another example of an ad hoc policy position was endorsement in 1926 of the "aims and activities of the American Association for Medical Progress," an organization made up of prominent academics and civic leaders to support science, especially animal experimentation (126).

In 1950, as federal support of scientific research was rapidly rising, the ASCI Council started explicitly to discuss the possibility of the ASCI taking a policy position on federal research support. They initially felt that individual members should not make their personal opinions known through the ASCI but instead "through other societies, their own institutions, or boards and committees on which they serve," an approach that would lead perforce to lobbying efforts that were scattered and uncoordinated. Perhaps as a result of the increasing dependence of ASCI members on federal research funds, perhaps as a response to public criticisms of biomedical research, starting in the 1960 s the ASCI as a society started to take policy positions on issues involving biomedical research funding (127). Sometimes the stand opposed onerous quarterly reporting requirements, sometimes the Council argued against limiting changes in the direction of funded research. In 1970 ASCI representatives were encouraged to testify before Congress that basic research (italics in original) would save money. Subsequent years were marked by both discussion of research grant policy and concerns that the ASCI is a "politically powerless" organization (128). A 1997 survey revealed that nearly $80 \%$ of ASCI members wanted the society to take stands on public policy.

In support of that goal, in 1998 the ASCI became the 12th full member of the Federation of American Societies for Experimental Biology (FASEB), hoping that FASEB would enable policy mak- 
ers to hear not a cacophony of small requests, but one consensus voice. The ASCI worked with FASEB to enhance the NIH budget and to support physician-scientists, especially physicians in clinical research, who since 1979 had been labeled an "endangered species" (129). Hoping to encourage more people to remain in academic positions, the ASCI and FASEB helped to craft a loan repayment program. But despite the national salience of science and scientific research, science policy continues to receive scant attention in national policy debates (130).

\section{Epilogue or prologue?}

It is hardly surprising that the ASCI of 2009 is very different from that of 1909. The fundamental tenets of clinical research, its definitions, techniques, and traditions, have all undergone the sorts of profound transitions and transformations one would expect over the course of 100 years (Figure 9). Likewise, the social context in which the ASCI exists has also changed dramatically.

Yet something else has changed. One hundred years ago, the first ASCI meeting brought together a group of revolutionaries trying to establish a new model for doing clinical research. They succeeded. They won. Over the course of the century, the Young Turks have become the status quo. Today, in 2009, the ideas that provided the impetus for change have become mainstream. The "Sultan has crept back into the palace" (131). Rather than being a marker for radical transformation, the ASCI has become a marker for academic success. Again, this transformation is hardly surprising. Revolutionary movements, in whatever field, rarely persist as revolutionary over the course of a century. They either succeed or die. And the ASCI did not die.

But it has changed, and it will continue to change. What will the ASCI be like a century hence? Will it be a home for innovative and creative challenges to established orthodoxy? Or will it be a means of sustaining the status quo? Answering these questions requires a different set of disciplinary skills - history is not prophecy. But history does serve to remind us, first, that the world will change, that established notions about what defines science and scientific excellence have changed and will continue to change. Historical analysis also reminds us that the ASCI will continue to reflect the changing social, political, and economic context in which it exists and to suggest some of the questions that will continue to be asked about the society.

Notes on sources. Much of the narrative description comes from the administrative records of the society, the Secretary's Book, Council Minutes, and records of the annual meetings. Records from 1907 to 1977 are located in the History of Medicine Division of the National Library of Medicine, Bethesda, Maryland, USA. More recent records are housed at the ASCI national office, Ann Arbor, Michigan, USA. Some of this material is paginated; most is not. Specific citations are provided only if the source (Council minutes, committee reports) is not located in the chronologically ordered archival administrative records. Other useful archival records are to be found in various holdings of the Rockefeller Archive Center, Sleepy Hollow, New York, USA. The entire run of the JCI - including the 50th-anniversary history of the ASCI (66), with much more detail on many topics - is available free online at http://www.jci.org/archive.

\section{Acknowledgments}

I appreciate careful readings and discussions of the manuscript by David Ginsburg, Halsted R. Holman, Powel Kazanjian, William N. Kelley, and Sanjay Saint. Staff at the History of Medicine Division of the National Library of Medicine and the Rockefeller Archive Center were extremely helpful. Toby Appel provided assistance in obtaining information about Phyllis Bodel. Writing of this paper was supported by a grant from the American Society for Clinical Investigation.

Address correspondence to: Joel D. Howell, Departments of Internal Medicine, History, and Health Management $\&$ Policy, University of Michigan, 300 N. Ingalls Bldg., Room 7C27, Ann Arbor, Michigan 48109-5429, USA. Phone: (734) 936-9832; Fax: (734) 936-8944; E-mail: jhowell@umich.edu.
1. Holt, L.S. 1906. A sketch of the development of the Rockefeller Institute for Medical Research. Science. 24:1-6.

2. Means, J.H. 1959. Experiences of a medical teacher. Perspect. Biol. Med. 2:127-192.

3. Lusk, G. 1915. On the proposed reorganization of departments of clinical medicine in the United States. Science. 41:531-534.

4. McRae, T. 1935. The early history of the Association of American Physicians. Trans. Assoc. Am. Physicians. 50:15-23.

5. King, L.S. 1983. Clinical science gets enthroned. JAMA. 250:1169-1172.

6. Ackerknecht, E.H. 1967. Medicine at the Paris hospital. Johns Hopkins University Press. Baltimore, Maryland, USA. 242 pp.

7. Metzl, J.M., and Howell, J.D. 2006. Great moments: authenticity, ideology, and the telling of medical "history." Lit. Med. 25:502-521.

8. Hill, C. 1972. The world turned upside down: radical ideas during the English Revolution. Viking Press. New York, New York, USA. 351 pp.

9. Wallace, G.B. 1921. A tribute to Dr. Meltzer's life and services. In Memorial number for Samuel James Meltzer, M.D. The New Era Printing Company. Lancaster, Pennsylvania, USA. 11-16.

10. Harvey, A.M. 1978. Samuel J. Meltzer: pioneer catalyst in the evolution of clinical science in America. Perspect. Biol. Med. 21:431-440.

11. Corner, G.W. 1964. A history of the Rockefeller Institute
1901-1953: origins and growth. Rockefeller Institute Press. New York, New York, USA. 635 pp.

12. Fordtran, J.C. 1977. An ASCI tradition. J. Clin. Invest. 60:271-275.

13. Christian, H.A. 1935. The President's address. Trans. Assoc. Am. Physicians. 50:1-7.

14. Meltzer, S.J. 1915. The deplorable contrast between intranational and international ethics and the mission of medical science and medical men. Science. 41:515-523.

15. Meltzer, S.J. 1914. Headship and organization of clinical departments of first-class medical schools. Science. 40:620-628.

16. ASCI Secretary's Book. ASCI Archives, 1907-1965. History of Medicine Division, National Library of Medicine, Bethesda, Maryland, USA.

17. Meltzer, S.J. 1909. The science of clinical medicine: what it ought to be and the men to uphold it. JAMA. 53:508-512.

18. Emerson, H. 1911. Blood pressure in tuberculosis. Arch. Intern. Med. 4:441-467.

19. [No authors listed]. 1918 May 7. Calls federal policy menace to medicine: Dr. Blumer says attitude of Surgeon General's office to medical schools is serious. The New York Times. 13.

20. Christian, H.B. 1919. Work of the medical clinic. JAMA. 73:637.

21. Cohen, A. 1928. Correspondence to Joseph Wearn. February 20. A.E. Cohn Papers. Folder 12, Box 1. Rockefeller Archive Center. Sleepy Hollow, New
York, USA.

22. Rowntree, L. 1919. The spirit of investigation in medical science. Science. 54:179-183.

23. Thompson, L.D. 1953. Early history of the Central Society for Clinical Research. J. Lab. Clin. Med. 41:3-5.

24. Cole, R. 1921. Memorandum concerning the publication of a new journal. April 1. Publications/Journals. Folder 3. Rockefeller Archive Center. Sleepy Hollow, New York, USA.

25. Robinson, G.C. 1923. Correspondence to Simon Flexner. May 18. Publications/Journals. Folder 3. Rockefeller Archive Center. Sleepy Hollow, New York, USA.

26. [No authors listed]. 1924 March 25. ASCI meeting minutes.

27. Cohn, A.E. 1924. Purposes in medical research: an introduction to the Journal of Clinical Investigation. J. Clin. Invest. 1:1-11.

28. Cohn, A. 1925. Correspondence to G. Canby Robinson. December 3. A.E. Cohn Papers. Folder 14, Box 1. Rockefeller Archive Center. Sleepy Hollow, New York, USA.

29. Cohn, A. 1927. Series 1.5 Appropriations. May 6. Folder 7383, Box 716. General Education Board Archives. Rockefeller Archive Center. Sleepy Hollow, New York, USA.

30. Austin, J.H. 1927. Report to the Council of ASCI, 1927, by Dr. J. Harold Austin.

31. Robinson, G.C. 1926. Correspondence to Simon 
Flexner. April 30. Publications/Journals. Folder 3. Rockefeller Archive Center. Sleepy Hollow, New York, USA.

32. Robinson, G.C. 1929. G. Canby Robinson memo. May 10. Series 1.5 Appropriations. Folder 7383 , Box 716. General Education Board Archives. Rockefeller Archive Center. Sleepy Hollow, New York, USA

33. [No authors listed]. [Date unknown.] Editor's Note. A.E. Cohn Papers. Folder 2, Box 2. Rockefeller Archive Center. Sleepy Hollow, New York, USA.

34. [No authors listed]. 1934. Typescript regarding Robinson stepping down. May 29. Folder 3, Box 2. Alfred Cohn Papers. Rockefeller Archive Center. Sleepy Hollow, New York, USA.

35. [No authors listed]. $1926 \mathrm{May} 3$. Hotel to be clinical laboratory. The New York Times. 11.

36. [No authors listed]. 1926 May 4. Blood speed timed through the body. The New York Times. 24.

37. Chase, M. 1987 May 4. Tests show human protein, GM-CSF, may treat anemia in AIDS patients. The Wall Street Journal. 36

38. [No authors listed]. 1936 May 5. Atomic force used to treat disease. The New York Times. 17

39. Lawrence, J.H., and Lawrence, E.O. 1936. Comparative biological effects of neutron rays and X-rays [abstract]. In Proceedings of the Twenty-Eighth Annual Meeting of the American Society for Clinical Investigation. May 4. Atlantic City, New Jersey, USA. J. Clin. Invest. 15:457.

40. [No authors listed]. 1939 May 2. Anesthetics vary in effect on brain. The New York Times. 25.

41. Beecher, H.K. 1939. Activity in the central nervous system during anesthesia [abstract]. In Proceedings of the Thirty-First Annual Meeting of the American Society for Clinical Investigation. May 1. Atlantic City, New Jersey, USA. J. Clin. Invest. 18:472.

42. Strickland, S.P. 1972. Politics, science, and dread disease: a short history of United States medical research policy. Harvard University Press. Cambridge, Massachusetts, USA. 329 pp.

43. Rosen, G. 1965. Patterns of health research in the United States, 1900-1960. Bull. Hist. Med. 39:201-222.

44. Bush, V. 1945. Science: the endless frontier. A report to the President on a program for postwar scientific research. United States Government Printing Office. Washington, DC, USA. 184 pp.

45. Swain, D.C. 1962. The rise of a research empire: NIH, 1930 to 1950 . Science. 138:1233-1237.

46. Allen, E.M. 1980. Early years of NIH research grants. NIH Alumni Association Newsletter. 2:6-8.

47. Francis, T. 1946. Biological beachheads. In Proceedings of the Thirty-Eighth Annual Meeting of the American Society for Clinical Investigation. May 27. Atlantic City, New Jersey, USA. J. Clin. Invest. 25:906-907.

48. Dingle, J.H. 1949. Correspondence to Thomas Hale Ham. October 27. Alfred Cohn Papers. Folder 4, Box 2. Rockefeller Archive Center. Sleepy Hollow, New York, USA.

49. Ham, T.H. 1950. The man and quality in clinical investigation. In Proceedings of the Forty-Second Annual Meeting of the American Society for Clinical Investigation. May 1. Atlantic City, New Jersey, USA. J. Clin. Invest. 29:792-794.

50. Loeb, R.F. 1936. Comments on clinical investigation. Science. 83:423-424.

51. Albright, F. 1944. Some of the "do's" and "do-nots" in clinical investigation. In Proceedings of the ThirtySixth Annual Meeting of the American Society for Clinical Investigation. May 8. Atlantic City, New Jersey, USA. J. Clin. Invest. 23:921-926.

52. [No authors listed]. 1948. Letter from the Editors. J. Clin. Invest. 27:689.

53. Harvey, A.M. 1956. The individual in medical research and the role of the university center in his training. In Proceedings of the Forty-Eighth Annual Meeting of the American Society for Clinical Investigation.
April 30. Atlantic City, New Jersey, USA. J. Clin. Invest. 35:683-686.

54. Burnham, J.C. 1982. American medicine's golden age: what happened to it? Science. 215:1474-1479.

55. Mullan, F. 2000. The case for more U.S. medical students. N. Engl. J. Med. 343:213-217.

56. Osmundsen, J.A. 1961 May 2. Researchers cite medicine's gains. The New York Times. 39.

57. [No authors listed]. 1952 May 19. The Young Turks. Time. http://www.time.com/time/magazine/ article/0,9171,816462,00.html.

58. Marks, P.A. 2008. The American Society for Clinical Investigation - the first 100 years. J. Clin. Invest. 118:1223-1334.

59. Lefkowitz, R.J. 2008. The Annual ASCI Meeting: does nostalgia have a future? J. Clin. Invest. 118: $1235-1233$.

60. Cohn, A.E. 1935. Cohn letter to editorial board. February 1. Alfred Cohn Papers. Folder 4, Box 2. Rockefeller Archive Center. Sleepy Hollow, New York, USA.

61. Berliner, R.W. 1960. Problems of the Society. J. Clin. Invest. 39:966-968.

62. Kelley, A.N. 2008. ASCI: reflections on the first 100 years and a proposal for the next. J. Clin. Invest. 118:1217-1219.

63. Fauci, A.S. 2008. The ASCI, the spring meetings, and growing up in academic medicine: a personal perspective. J. Clin. Invest. 118:1214-1217.

64. Nathan, D.G. 2007. Acceptance of the 2006 Kober Medal. J. Clin. Invest. 117:1111-1113.

65. Braunwald, E. 2008. The American Society for Clinical Investigation, 1952-1975: a personal perspective. J. Clin. Invest. 118:1228-1230.

66. Brainard, E.R. 1959. History of the American Society for Clinical Investigation, 1909-1959. J. Clin. Invest. 38:1784-1837.

67. Luetscher, J.A. 1959. Observations on growth and development of clinical investigation. In Proceedings of the Fifty-First Annual Meeting of the American Society for Clinical Investigation. May 4. Atlantic City, New Jersey, USA. J. Clin. Invest. 38:981-982.

68. Finch, C.A. 1961. The shape of clinical investigation. J. Clin. Invest. 40:1019-1021.

69. Schwartz, T.B. 2001. Two against McCarthyism: me and John Peters. Perspect. Biol. Med. 44:434-445.

70. Paul, J.R., and Long, C.N.H. 1958. John Punnett Peters, 1887-1955. Biogr. Mem. Natl. Acad. Sci. 31:347.

71. Beecher, H.K. 1966. Ethics and clinical research. N. Engl.J. Med. 274:1354-1360.

72. Rothman, D.J. 1991. Strangers at the bedside: a history of how law and bioethics transformed medical decision making. Basic Books. New York, New York, USA. 303 pp.

73. [No authors listed]. 1967. Declaration of Helsinki: recommendations guiding doctors in clinical research. J. Clin. Invest. 46:1140.

74. Liddle, G.W. 1967. The mores of clinical investigation. In Proceedings of the Fifty-Ninth Annual Meeting of the American Society for Clinical Investigation. May 1. Atlantic City, New Jersey, USA. J. Clin. Invest. 46:1028-1030

75. London, I.M. 1964. The impact of the revolution in biology on clinical investigation. In Proceedings of the Fifty-Sixth Annual Meeting of the American Society for Clinical Investigation. May 4. Atlantic City, New Jersey, USA. J. Clin. Invest. 43:1222-1224.

76. Hixson, J.P. 1976. The patchwork mouse. Anchor Press. Garden City, New Jersey, USA. 228 pp.

77. Altman, L.K. 1980 August 9. Columbia's medical chief resigns; ex-associate's data fraud at issue. The New York Times. 1, 8

78. United States House of Representatives. 1981. Fraud in biomedical research. Hearings before the Subcommittee on Investigations and Oversight of the Committee on Science and Technology, U.S. House of Representatives. United States
Government Printing Office. Washington, DC, USA. 380 pp.

79. Kevles, D.J. 1998. The Baltimore case. W.W. Norton. New York, New York, USA. 509 pp.

80. Braunwald, E., and Kloner, R.A. 1982. Notice of retraction of "Early recovery of regional performance in salvaged ischemic myocardium following coronary artery occlusion in the dog" [retraction of: Braunwald, E., and Kloner, R.A. 1981. J. Clin. Invest. 68:225-239]. J. Clin. Invest. 70:915.

81. Majerus, P.W. 1982. Fraud in medical research. J. Clin. Invest. 70:213-217.

82. Stiff, D. 1985 July 12 . Test-tube fraud: competition in science seems to be spawning cases of bad research. The Wall Street Journal. 1, 15.

83. Neill, U.S., and Turka, L.A. 2008. Bothered and bewildered, but not bewitched. J. Clin. Invest. 118:3516

84. Fauci, A.S. 2008. The ASCI, the spring meetings, and growing up in academic medicine: a personal perspective. J. Clin. Invest. 118:1214-1217.

85. Landefeld, C.S. 1993 . The spring meetings - are they dying? N. Engl. J. Med. 328:1645-1647.

86. Snyderman, R. 2004. The AAP and the transformation of medicine. J. Clin. Invest. 114:1169-1173.

87. Cohn, A. 1925. Correspondence to Canby Robinson. January 8. Alfred Cohn Papers. Folder 14, Box 1. Rockefeller Archive Center. Sleepy Hollow, New York, USA.

88. Ginzberg, E. 1999. The shift to specialism in medicine: the U.S. Army in World War II. Acad. Med. 74:522-525.

89. Moore, C.V. 1954. Presidential address. In Proceedings of the Forty-Sixth Annual Meeting of the American Society for Clinical Investigation. May 4. Atlantic City, New Jersey, USA. J. Clin. Invest. 33:912-913.

90. Wood, W.B. 1952. The "logarithmic phase" of medical progress. J. Clin. Invest. 31:611-613.

91. Williams, R.H. 1959. Departments of Medicine in 1970. I. Staff Policies. Ann. Intern. Med. 50:1252-1276

92. Petersdorf, R.G. 1980. The evolution of departments of medicine. N. Engl. J. Med. 303:489-496.

93. Fye, W.B. 1996. American cardiology: the history of a specialty and its college. Johns Hopkins University Press. Baltimore, Maryland, USA. 489 pP.

94. Stevens, R. 1988. The curious career of internal medicine: functional ambivalence, social success. In Grand rounds: one hundred years of internal medicine. R.C. Maulitz and D.E. Long, editors. University of Pennsylvania Press. Philadelphia, Pennsylvania, USA. 339-364.

95. Howell, J.D. 1989. Invention and development of American internal medicine. J. Gen. Intern. Med. 4:127-133.

96. Early, L.E. 1976. The Health of Clinical Investigation beyond Atlantic City. J. Clin. Invest. 57:1660-1665.

97. Bliss, M. 1982. The discovery of insulin. McClelland \& Stewart. Toronto, Ontario, Canada. 304 pp.

98. [No authors listed]. 1927. Minutes of the 1927 ASCI Council Meeting. ASCI archives, 1907-1965. History of Medicine Division, National Library of Medicine, Bethesda, Maryland, USA.

99. Kunkel, H. 1962. The training of the clinical investigator. In Proceedings of the Fifty-Fourth Annual Meeting of the American Society for Clinical Investigation. April 30. Atlantic City, New Jersey, USA. J. Clin. Invest. 41:1334-1336.

100.Melmon, K.L. 1979. A society without an obvious future: can elitism help? J. Clin. Invest. 64:342-349.

101.Morantz-Sanchez, R. 2000. Sympathy and science: women physicians in American medicine. UNC Press. Chapel Hill, North Carolina, USA. 464 pp.

102.More, E.S. 1999. Restoring the balance: women physicians and the profession of medicine, 1850-1995. Harvard University Press. Cambridge, Massachusetts, USA. 340 pp.

103.More, E.S., Fee, E., and Parry, M. 2009. Women physi- 


\section{historical perspective}

cians and the cultures of medicine. Johns Hopkins University Press. Baltimore, Maryland, USA. 357 pp.

104. Rossiter, M.W. 1982. Women scientists in America: struggles and strategies to 1940. Johns Hopkins University Press. Baltimore, Maryland, USA. 439 pP.

105. [No authors listed]. 1978. Phyllis Tuck Bodel, M.D. Yale Medicine. 13:19.

106. Rosenberg, L.E. 2008. MD/PhD programs - a call for an accounting. JAMA. 300:1208-1209.

107. Marks, A.R. 2005. Sex and the university system. J. Clin. Invest. 115:790.

108.Ley, T.L., and Hamilton, B.H. 2008. The gender gap in NIH grant applications. Science. 322:1472-1474.

109. Marks, A.R. 2005. Desperately seeking diversity. J. Clin. Invest 115:480.

110.Davenport, H.W. 1986. Fifty years of medicine at the University of Michigan, 1891-1941. University of Michigan Medical School. Ann Arbor, Michigan, USA. 525 pp.

111. Jarcho, S. 1959. Medical education in the United States -1910-1956. J. Mt. Sinai Hosp. N. Y. 26:339-385.

112. Harrison, T.R. 1939. Presidential address. In Proceedings of the Thirty-First Annual Meeting of the American Society for Clinical Investigation. May 1. Atlantic City, New Jersey, USA. J. Clin. Invest. 18:469-470.

113. Heyd, C.G. 1955. A tribute to Haven Emerson, M.D.
Bull. N. Y. Acad. Med. 31:869-871.

114.Suser, M. 1998. The Columbia University School of Public Health 75th Anniversary issue; introduction. Am. J. Epidemiol. 147:197.

115.Paul, J.R. 1973. An account of the American Epidemiological Society. A retrospect of some fifty years. Yale J. Biol. Med. 46:1-84.

116. Brandt, A.M., and Gardner, M. 2000. Antagonism and accommodation: interpreting the relationship between public health and medicine in the United States during the 20th century. Am. J. Public Health. 90:707-715.

117. Paul, J.R. 1938. President's address: Clinical epidemiology. J. Clin. Invest. 17:539-541.

118. [No authors listed]. 1949. Letter from the Editors: Clinical investigation. J. Clin. Invest. 28:408.

119.Savla, U. 2004. Reflecting on 80 years of excellence. J. Clin. Invest. 114:1006-1016.

120.Wilson, J.D. 1974. The Journal of Clinical Investigation 1974. J. Clin. Invest. 54:xv-xvii.

121. Bondy, P.K. 1959. History of the Journal of Clinical Investigation, 1924-1959. II. Scientific contents. J. Clin. Invest. 38:1873-1877.

122.Weiss, S.J. 1997. Speed, competition, rigor, and creativity: striking a delicate balance. J. Clin. Invest. 99:817-818.
123.Turka, L.A. 2008. Animal house. J. Clin. Invest. 118:822.

124.Goldstein, J.L., and Brown, M.S. 2008. From fatty streak to fatty liver: 33 years of joint publications in the JCI. J. Clin. Invest. 118:1220-1222.

125.Savla, U., and Hawley, J. 2004. The JCI gets a facelift. J. Clin. Invest. 113:848.

126. Colgrove, J. 2005. Science in a democracy. Isis. 96:167-191.

127. Merrill, J.P. 1963. Presidential address. In Proceedings of the Fifty-Fifth Annual Meeting of the American Society for Clinical Investigation. April 29. Atlantic City, New Jersey, USA. J. Clin. Invest. 42:906-908.

128.Franklin, E.C. 1974. The individual, science and society. In Proceedings of the Sixty-Sixth Annual Meeting of the American Society for Clinical Investigation. May 6. Atlantic City, New Jersey, USA. J. Clin. Invest. 53:1755-1760.

129. Wyngaarden, J.B. 1979. The clinical investigator as an endangered species. N. Engl. J. Med. 301:1254-1259.

130. Turka, L.A. 2008. Senator, what is your policy on ... "other"? J. Clin. Invest. 118:2988.

131. Weber, B.L. 2007. In the palace of the sultan. J. Clin. Invest. 117:1727-1731.

132.C.P. Emerson. 1928. Physical diagnosis. Philadelphia, Pennsylvania, USA. J.B. Lippincott. p. 311. 